\title{
The effect of a science festival for special education students on communicating science
}

\author{
Hyeran Park' ${ }^{1}$ Youngmin Kim ${ }^{2^{*}}$ (D) and Seongoh Jeong ${ }^{3}$
}

\author{
* Correspondence: \\ minkiyo@pusan.ac.kr \\ ${ }^{2}$ Pusan National University, \\ Busandaehakro, 63 bun-gil 2, Busan \\ 46241, Republic of Korea \\ Full list of author information is \\ available at the end of the article
}

\begin{abstract}
Science festivals have been reported as an effective way to communicate science between scientists and the public; however, only a few studies have examined systematically and consistently how the festivals effect the public's conceptions of science. Moreover, few studies about science festivals for special education students are conducted. This study is based on findings from five years of reflective writings and drawings on Seullim Science Festivals collected by the Busan Institute of Science Education in Korea. Seullim Science Festival aims to give opportunities for Special Education students to engage in a variety of science experiments and to enjoy the basic rights of science for all students. The rich qualitative data were analyzed using a ground theory and categorized by the themes. The findings presented in this paper show the impressions of the special education students on the festivals and their pride in being a participating member. Additionally, the festivals gave opportunities for non-special education students to become more insightful understanding to special education students and to engage in science. The authors of the current study hope other science festival organizers and science educators find the information useful.
\end{abstract}

Keywords: Science festival, Special education student, Non-special education student, Science communication, Attitude towards science

\section{Introduction}

Effective and good science communication is acknowledged as a crucial element that leads to a strong support on students' core competency for their scientific literacy. Increasing well developed communication between scientists and the public or young students expands knowledge of and about science. The depth of knowledge can encourage or inspire the young students to science-related fields for future career aspirations (Burns et al. 2003; Jensen \& Buckley 2012; Park et al. 2009). Researchers in the science communication fields (Burns et al. 2003; Jensen 2011, 2014a,b; Potocnik, 2005) argue that a science festival is a way to communicate science between scientists and the public, which is why many science festivals have been held around the world. Only a few, however, have systematically and consistently examined the effect of science festivals on learning, practicing and inspiring science, attitudes towards science or enhancing scientific literacy (Burns et al. 2003; Jensen, 2011; Jensen \& Buckley 2011). Jensen (2014a,b)

(c) The Author(s). 2019 Open Access This article is distributed under the terms of the Creative Commons Attribution 4.0 International License (http://creativecommons.org/licenses/by/4.0/), which permits unrestricted use, distribution, and reproduction in any medium, provided you give appropriate credit to the original author(s) and the source, provide a link to the Creative Commons license, and indicate if changes were made. 
pointed out that a few numbers of studies related to scientific festival are found problematic in their methodologies. They are heavily dependent on close-ended and simple survey data, so that the actual complexity and insightful feedback would not be revealed in the reports of science festivals. The authors of this study have searched studies on science festivals in Korea from the major journals of science education such as Journal of Korean Association for Science Education or the Research Database of the National Assembly Library of Korea and could find very few studies on this aspect, even though every year science festival has been held in many cities of Korea. In case of science fair related to competition among students or among science teachers, there are some studies about it.

Regarding the fairness of science, Osborne (2000) argues that science is an achievement of humanity that should be shared and a culture that does not exclude any individuals, so that everyone may benefit from it. Korean science curriculum explicitly states that science education is for all, regardless of individual's learning abilities. It emphasizes to cultivate scientific literacy as well (Ministry of Education of Korea, 2015). However, students who suffer from learning disabilities or physical difficulties mostly lack opportunities to participate in science experiments as well as experiencing science festivals, comparing with Non-Special Education (NSE) students and the average public. This fact is the opposition to the idea that everyone should share the benefits of science (Im et al. 2018; Kang \& Martin, 2017). In Busan, Korea, from 2012, a science festival, named Seullim Science Festival for special education (SE) students, has been held every year to share the heritage of a culture, to provide diverse scientific experiences and to achieve science for all. Through participating the SSF, special education students can learn science concepts and scientific skills, and non-special education students can understand special education students by cooperation each other.

The present study intends to report the findings from five years of reflective writings and drawings of SE and NSE students who either visited or participated in running science experience booths and helped the festivals. It examined the data focusing on the following points:

1) What and how NSE students felt when they attended the festivals;

2) How the learning of science (Hodson, 2008; McComas, 2004) and the practice of science (National Research Council, 2013) occurred and how the attitudes toward science of both the participants and the visitor students were changed; and

3) How science communication occurred effectively between the science experiment booth runners, teachers (participants) and the SE visitor students.

Utilizing a grounded theory approach (Glaser \& Strauss, 1967) as well as a formulated conceptual framework, the collected data sources of the reflective writings and drawings were analyzed. The findings will be a stepping-stone towards shedding light on the role of future science festivals in science communication, particularly for SE students. Based on the findings, the authors have a few recommendations for any organizers who plan to launch a science festival for special education students.

\section{Literature review and a conceptual framework for analysis}

In a democratic society, the idea that the public should be able to understand the basics of science to make an informed decision is widely recognized (Hodson, 2008; 
Holliman \& Jensen, 2009; Irwin, 2006; Jensen, 2011, 2014a,b; Ministry of Education of Korea, 2015). Science communication refers to the communication between scientists or experts and the public to inform scientific works, to improve scientific literacy of the public, or to gain public support using appropriate skills, media, activities and dialogue (Bultitudes, 2011; Burns et al., 2003; Myers, et al., 2018). Such forms of communication involve science practitioners, mediators, and other members of the general public, by peer-to-peer or between groups (Burns et al. 2003).

For the public awareness and understanding of science, communicating with science between scientists and the public is crucial. Good communication can lead the public to have informed views on science while poor communication may lead them to mistrust or misunderstand scientific research results and scientists. According to Potocnik (2005), science festivals or science days are Science Communication Events (SCE) "to raise the public awareness and understanding of science, technology, and the humanities... and to promote the dialogue between science and society...to encourage young people into science" (p. 5).

Through science festivals, science is manifested to the general public in an accessible and interesting way. The benefit of a science festival as a way of science communication is the two-way flow between scientists and the public. Studies suggest the two-way communications as a contextual model (Burns et al., 2003; Gross, 1994), which "public understanding is the joint creation of scientific knowledge." (Burns et al., 2003, p.180). Concerning SE students, Im et al. (2018) shows that a specially designed equipment was employed to explain the nature of light for the students who have visual difficulties. The researchers collaborated with preservice teachers and presented a play on light dispersion for the hearing impairment students as well. Regarding the diverse approaches to scientific experiences and individualized methods, a science festival is optimal events for SE students.

Burns et al. (2003), and Jensen (2014a,b) examined why people visit a science festival. According to Jensen (2014a,b), visitors valued the opportunities to attend a science festival, to interact with scientists, and to encounter scientific phenomena. He also reported that their interests and curiosity about new areas of science have increased after their attendance. Particularly, Burns et al. (2003) categorized the reasons using the analogy of the letters that are associated with vowel sounds, A, E, I, O, U:

- People are $A$ ware of science and scientific research;

- People Enjoy science and appreciate it as an entertainment or arts;

- The public have Interests in science communication as evidenced by voluntary involvement;

- The public have $\boldsymbol{O}$ pinions on science either positive or negative attitudes and;

○ The public have some $\boldsymbol{U}$ nderstanding of its content, processes and social factors.

Their findings provide the basis of the conceptual framework of this study. As the aim of this paper is to report the SE students' impressions when they attended the Seullim Science Festival(SSF), Burns et al.' categorization (2003) is suitable for analyzing the authors' findings. Also, it can be examined what the visitors and participants (the science experience booth runners) learned through the festival in terms of learning 
science and learning about science (Hodson, 2008; McComas, 2004). These elements are combined with above findings for constructing the conceptual framework of this study.

\section{Methodology}

Research context

Seullim ${ }^{1}$ Science Festival (SSF) has been held by the Busan Institute of Science Education (BISE) in Korea since 2012. It aims to provide opportunities for SE (Special Education) students with experiences of science as well as for NSE (Non-Special Education) students to increase their understanding towards SE students. Its slogan is "Through science we become one: Not just for SE students, but with SE students." It emphasizes science as the mediator to integrate SE and NSE students, and encourages SE students to participate actively in SSF.

BISE received applications from schools and invited societal community groups to run science experimental booths. Although BISE did not limit regional restrictions, most applied schools were from the Busan Metropolitan City District School Board. Unfortunately, not many of the societal community groups joined; however, once they participated, they were willing to continue.

The uniqueness of SSF was the active participation of SE students alongside NSE students and rich communication between the two groups. Unlike other science festivals in the country, SE students did not have a passive role such as visitors, but they conducted the booths by themselves or with NSE students. In addition, while they were selecting topics, and facilitating methods, rich communication occurred on what needs to be done, how it should be done and what role each student should have. Through these procedures NSE students realized that SE students have their own merits.

The authors identified the students into three groups: 1) SE students who visited SSF, 2) SE students who ran science experimental booths and 3) NSE students who ran science experimental booths. SE students belong to 15 special education schools or special classes within typical schools. Here, the booth running students were frequently referred as participants. BISE could count the numbers of participants and SE visiting students correctly since it provided the registered booth runners with lunch and T-shirts, and visiting SE students with name tags and eco-bags to carry science booth goodies.

Table 1 shows the numbers who participated at the SSF during five years (2012 2016). SE students that attended the festival fluctuated depending on the day the festival was

Table 1 The Features of SSF

\begin{tabular}{lllll}
\hline Year & $\begin{array}{l}\text { SE students } \\
\text { (visitors out of total) }\end{array}$ & NSE visiting students & $\begin{array}{l}\text { Total Number of booths } \\
\text { (SE students' booths) }\end{array}$ & Ref \\
\hline 2012 & $1837 / 4481(41 \%)$ & 507 & $39(1)$ & 1 day \\
2013 & $3743 / 5128(73 \%)$ & 984 & $67(3)$ & 2 week days \\
2014 & $2072 / 4819(43 \%)$ & 973 & $72(10)$ & 1 week and 1 weekend day \\
2015 & $2368 / 4873(49 \%)$ & 7500 & $80(12)$ & 1 week and 1 weekend day \\
2016 & $2637 / 4883(54 \%)$ & 5300 & $84(14)$ & 2 week days \\
\hline
\end{tabular}


held because most of them could not visit SSF alone. During the weekend, their teachers or assistants were not available, their attendance was low. In 2013 and 2016, SSF opened for 2 weekdays, 73\% and 54\% of the total SE students in Busan visited, respectively, while in the other years 2014 and 2015, it opened on Friday and Saturday, the numbers decreased to $43 \%$ and $49 \%$, respectively. For SE students, week days seemed to be better for their attendance.

Shown in Table 1, the teams running the science experience booths have gradually increased from 39 teams in 2012 to 84 teams in 2016. This increasing number of applying teams implies that SSF is acknowledged as a valuable event for science communication and collaboration between SE and NSE students. In 2012 and 2013, one and three special schools participated in and ran science experience booths, respectively. From the year 2014, however, ten or more out of 15 SE schools in Busan and 20 or more combination groups of NSE and SE students participated in. The rests were run by NSE schools and society science organizations.

In order to have a booth, the schools had to apply. With the increasing popularity of SSF, the special education school teams had priority, and the combined teams with SE and NSE students were second. The appropriateness of the content for the SE students in terms of safety and the degree of complexity was taken into consideration. As an example, the content of the science experiments in 2014 is shown in the Appendix.

To ensure effective communication between SE and NSE students, to all performing students (booth running students) and their supervising teachers were given a two-hour lecture by a specialist in the special education field. The lecture was focused on the characteristics of SE students and how to reduce bias views about them. In addition, BISE distributed a book and CD with the content of booths so that the special education teachers might select the proper topics for their students, and so that they could give their SE students an idea of SSF.

In SSF (Fig. 1), the visitors, particularly SE students, got involved by experiencing science and scientific principles with hands-on activities which allowed them to gain the applied knowledge. Figure 2 shows an example of how communication took place in the form of participating students wearing blue shirts explaining a hands-on activity and helping the visitor SE students.

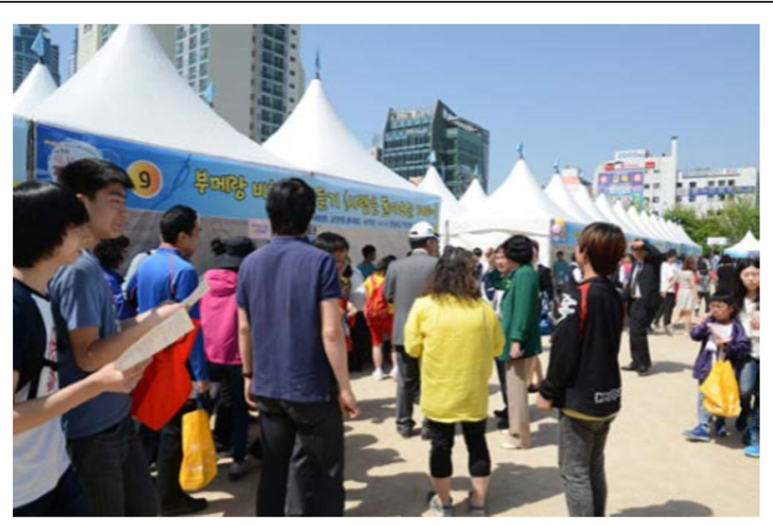

Fig. 1 A panoramic view of Seullim Science Festival 


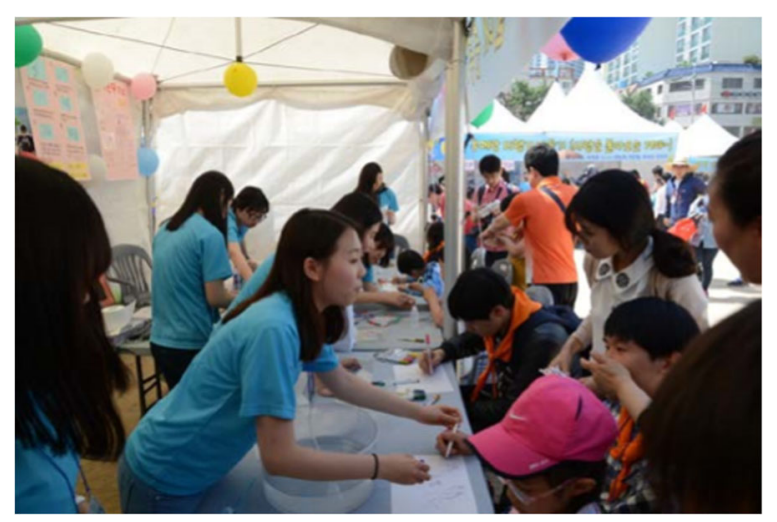

Fig. 2 A feature of a science experience booth

\section{Data resources}

Concerning the data source formats, Jensen and Buckley (2011) pointed out that the close-ended survey questionnaires lacked validity and reliability because they were too simple to include the complexity of science festivals and diversity of visitors. Thus, an effort was made in this study to compensate for the shortcomings from the previous studies. After the festival, the participating students who ran the booths, the teachers and community science organization members, and the SE students in SSF were asked to submit written reflections, photos or drawings about what they learned and felt from SSF. The submissions were voluntary and had no restrictions or guidelines for format in the writing or drawings. We included photos and drawings because SE students could have difficulties in expressing what they learned and felt through writing.

As Table 2 describes, the submissions of scientific work by participants increased over the years. In 2014, SE and NSE students and participating teachers submitted 372 works; 124 were drawings or photos with a couple of sentences submitted by SE visitor students, 245 were written reflections submitted mostly by NSE students and 3 were by SE students. Eleven participating teachers also submitted the survey. No community science organization members submitted reflections.

\section{Data analysis}

Two stages were adopted to analyze the data: A grounded theory approach (Gibbs, 2010; Glaser \& Strauss, 1967) and, Burns et al.'s vowel sound analogies. According to

Table 2 Number of Submitted Reflection Writings and Drawings of SSF

\begin{tabular}{lllll}
\hline Year & SE visitor students & SE booth runners & NSE booth runners & Total \\
\hline 2012 & 32 & 0 & 44 & 76 \\
2013 & 142 & 0 & 98 & 240 \\
2014 & 124 & 3 & 245 & 372 \\
$2015^{\text {a }}$ & - & - & - & - \\
2016 & 81 & 8 & 22 & 111 \\
Total & 379 & 11 & 409 & 831 \\
\hline
\end{tabular}

${ }^{a}$ In 2015, there was a ship sinking accident in Korea, and the scale of the festival was reduced and no reflection writings and paintings were collected 
Glaser and Strauss (1967), the grounded theory is "the discovery of theory from data systematically obtained from social research" (p.2). The reasons for the use of the grounded theory were that the data were not a pre-formatted survey questionnaire. Students who submitted the reflective writings and drawings were kindergarten to grade12 and 15 special education schools. They wrote and drew without any limitations or guidelines. The data varied in its length, content, format and focuses. This method benefits for the authors to discover students' conceptions of science and the role of science festivals in mutual understandings without any prior conceptions. In the second stage of the data analysis, Burns et al.'s (2003) vowel sound analogy was employed to categorize the common themes.

At the beginning of the data analysis, open coding was carried out to identify the emergent and common themes (the coding processes included labeling, grouping, etc.) The major and common themes were extracted and classified after discarding irrelevant information. The authors of this study labeled the data, the representative quotations were selected from the major categories. Mutually exclusive data were merged. The processes were conducted exhaustively, and then the conceptual framework (Table 3) was formulated.

Table 3 illustrates the conceptual framework for analyzing the visitors and participants' reflection after the science festival. The first main category is about the impressions and feelings after visiting or participating in a science festival, which are based from Burns et al.'s (2003) vowel sound analogies: Aware, Enjoy, and Interests. The second main category is about the elements of learning of/about science (Hodson 2008), including Burns et al.'s (2003) Opinions and Understanding sub-categories. The sub-categories depict the key words representing qualitative data. Science communication implies how the communication occurs between the participants and the visitors in the science festival.

Table 3 Conceptual framework

\begin{tabular}{|c|c|c|c|}
\hline Main category & Sub-category & Key words/ representations & Science communication \\
\hline \multirow[t]{3}{*}{$\begin{array}{l}\text { feelings/impressions } \\
\text { of a science festival }\end{array}$} & Awareness & $\begin{array}{l}\text { be aware/know/learn } \\
\text { knowledge/information }\end{array}$ & $\begin{array}{l}\text { The previous knowledge/information } \\
\text { about science was brought one to a } \\
\text { science festival confirmed, learned, } \\
\text { broadened, in-depth } \\
\text { knowledge/information }\end{array}$ \\
\hline & Enjoyment & $\begin{array}{l}\text { fun/ excited/exciting/want } \\
\text { to come again }\end{array}$ & $\begin{array}{l}\text { Experiencing the content of science } \\
\text { festivals provides visitors/participants } \\
\text { with enjoyment of science }\end{array}$ \\
\hline & Interests & $\begin{array}{l}\text { voluntarily involvement/ } \\
\text { participation }\end{array}$ & $\begin{array}{l}\text { The experiences of science festivals } \\
\text { encourage students to participate } \\
\text { in/visit science festivals }\end{array}$ \\
\hline \multirow[t]{3}{*}{$\begin{array}{l}\text { Understanding/Learning } \\
\text { of/about science through } \\
\text { a science festival }\end{array}$} & $\begin{array}{l}\text { Attitudes } \\
\text { towards science }\end{array}$ & $\begin{array}{l}\text { I changed my conceptions } \\
\text { of science } \sim \text {, l learned } \\
\text { science is } \sim\end{array}$ & $\begin{array}{l}\text { Fun and exciting experiences of } \\
\text { science festival can change } \\
\text { students' negative impressions } \\
\text { into positively or can inspire their } \\
\text { future careers in science areas. }\end{array}$ \\
\hline & Learning science & $\begin{array}{l}\text { learning } \\
\text { understanding } \\
\text { understood }\end{array}$ & $\begin{array}{l}\text { Many different hands-on activities } \\
\text { in the science festival motivate } \\
\text { (help) for students to learn } \\
\text { (understand) science }\end{array}$ \\
\hline & $\begin{array}{l}\text { School science } \\
\text { learning }\end{array}$ & school science classes & $\begin{array}{l}\text { Informal science learning can } \\
\text { positively affect the school } \\
\text { science learning. }\end{array}$ \\
\hline
\end{tabular}


Before starting the analysis, the works of SE, NSE students and teachers were separated to compare if there were any differences. Pseudonyms were used when students' excerptions were cited.

\section{Results}

The SE student' works are mostly just drawings or drawings with a few sentences. On the other hand, NSE students' and teachers' works are mostly in writing. The first step of data analysis provided broad themes such as their experiences and impressions. Since SSF is a science festival for/with SE students, we could find many works mentioning about science communication and understanding between the two groups of students, therefore, the science communication and the understanding between NSE and SE students were a significant part of the results. The teachers' works were mostly about suggestions to better SSF. They emphasized the accessibility of the venue and the available facilities, which were not directly used to science communication. Thus, the teachers' works are discussed in the concluding remarks.

Like Burns et al.'s study (2003), this study identified the vowel sound elements (Awareness, Enjoyment, Interest, Opinions and Understanding) except awareness of science and scientific research. The absence of this could be related to the intention of SSF, which is mostly about the fairness of science for all rather than informing new scientific research to the public.

The results are shown by three categories. First two categories, according to the conceptual framework (Table 3), are the feelings and impressions of the students and what they learned in the festival. The subcategories of the feelings and impressions include Awareness, Enjoyment and Interests in involvement. The subcategories of what they learned in the festival include learning the content of science and learning about science (the problem-solving procedures and how to collaborate with peers). The third category is added, which is the understanding between NSE students and SE students.

\section{Awareness and enjoyment}

The key words for awareness are "be aware, know, information about," and the key words for enjoyment are "fun, exciting, interesting, wanting to visit SSF again, happy, curious." In students' reflections, there are very few expressions about awareness of SSF. The reason may be because their attendance was decided by school teachers, not by themselves. For example, "When I heard about this festival from my teacher ..." or "... my friend asked me if I would attend the festival," etc. were found. Reflections of Enjoyment are mostly found from SE student submissions. In Fig. 3, the left side drawing made by a grade $7 \mathrm{SE}$ student shows smiles and enjoyment. About 91\% of SE students thought SSF was a fun event. However, $5 \%$ of the students felt scared when they faced such unfamiliar experiences being firefighters or astronauts. The fear occurred when they found the hands-on activities difficult and when they were not satisfied with the outcomes. As a result, they lost their interests, "I made an earphone by transferring vibrations from our teeth, but it did not work. It was difficult to make. I lost interest in making it." (Hyesong).

SE students expressed the enjoyment of SSF as follows: 


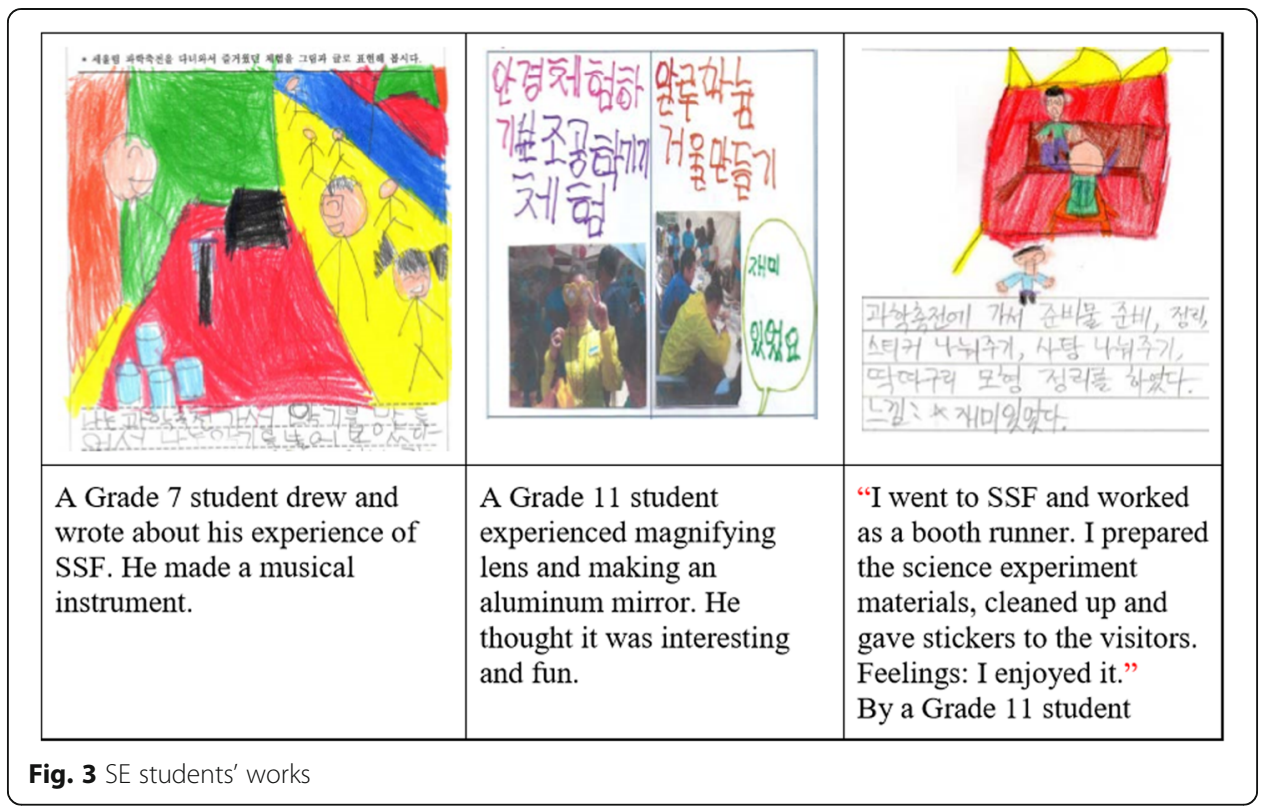

When a ladybug was heated by the sun light, it started to dance. It was amazing and interesting. I was very interested and curious about it. (Haenam)

When a girl put a cup behind a mirror, shockingly it disappeared. If I put Wonjin [friend's name] behind the mirror, would he also disappear? The phenomenon was really fun and I enjoyed it. (Hyesong)

I made a beautiful eraser. I made a luminous bracelet.

I enjoyed the festival. It was really fun. (Munhwa)

On the other hand, NSE students enjoyed the moment when SE students thanked them, as they felt that helping SE students was an achievement. They also expressed happiness of experiencing SSF, because it provided a great memory. Furthermore, through SSF, their understanding of SE students expanded. The followings are the excerpts from NSE students' writings:

I was happy when a SE student smiled and said, "Thank you." When I heard their thanks and saw their smile, I was happier than when I got good scores in my examinations.

(Daeduk)

Due to preparations for the university entrance exam, I was melancholic, but I could release stress in SSF. I really enjoyed SSF. I had a good time. (Namsung)

When I had to spend a lot of time preparing for the booth, I was nervous and regretted my decision to participate in SSF, because I regarded it as a waste of time. However now, I don't regret participating in SSF, rather I want to attend SSF next year. (Donglae) 
I am an introverted person and I used to be nervous speaking in front of others. As far as I remember, this is the first time I spoke and shared my knowledge with others. It was a great experience. I enjoyed SSF a lot and I am very proud of myself. (Haeundae)

She [an SE student] reminded me of the autumn sun light, which is not too strong like summer light, and not warm like spring light, but rather cool. When she completed each stage, she clapped and smiled. She made me think to myself, "Am I such a person to give pleasure and happiness to others?” ... SSF was very meaningful to me. (Haedong)

Running the science experiment booths was very tiring, but the participants felt happy when they could do something useful and good for others, especially for SE students. They felt pride in themselves and they found some positive characteristics in their own personality.

Out of all students' reflection writings or drawings, 298 SE visitors', 3 SE booth runners', and 387 NSE students' reflections were analyzed. Table 4 shows the number of students who expressed their feelings of enjoyment and how the communication occurred. Effective science communication occurred when the activities of SSF matched well with SE students' existing experiences and when they had satisfying outcomes from hands-on activities. The fun activities, diligently prepared by the NSE student, drew SE students' attention and made them enthusiastically involved in the festival. Additionally, they tried to understand SE students' characteristics, thoughts, and personalities, so that they could be patient as they kindly gave repeated explanations.

Table 4 Analysis on SE and NSE students' feeling of enjoyment

\begin{tabular}{|c|c|c|c|c|c|}
\hline \multirow[t]{2}{*}{ Subthemes } & \multirow[t]{2}{*}{ Key words } & \multicolumn{2}{|c|}{ No. of SE students (\%) } & \multirow{2}{*}{$\begin{array}{l}\text { No. of NSE }(\%) \\
(N=387)\end{array}$} & \multirow{2}{*}{$\begin{array}{l}\text { When did students feel } \\
\text { enjoyment? (Kinds of activities) }\end{array}$} \\
\hline & & $\begin{array}{l}\text { Visitor } \\
(N=298)\end{array}$ & $\begin{array}{l}\text { Participants } \\
(N=3)\end{array}$ & & \\
\hline $\begin{array}{l}\text { Curiosity/Competing } \\
\text { with friends }\end{array}$ & $\begin{array}{l}\text { *fun, } \\
\text { *curious, }^{*} \text { *exciting } \\
{ }^{*} \text { want to } \\
\text { visit again } \\
\text { *happy }\end{array}$ & $270(90.6 \%)$ & & & $\begin{array}{l}\text { New experiences } \\
\text { Unexpected experimental } \\
\text { results (e.g., the polarized } \\
\text { light made a cup disappear) } \\
\text { Curious phenomena } \\
\text { Beautiful outcomes } \\
\text { Usefulness of the outcomes }\end{array}$ \\
\hline No enjoyment & $\begin{array}{l}\text { *Scared, } \\
\text { *nervous } \\
\text { *Difficult } \\
\text { *Not } \\
\text { interesting }\end{array}$ & $14(4.7 \%)$ & $2(67 \%)$ & $67(17.1 \%)$ & $\begin{array}{l}\text { Experiences were not } \\
\text { familiar to SE students } \\
\text { The ear phone did not work. } \\
\text { New experiences, worry } \\
\text { about explaining to others }\end{array}$ \\
\hline Kindness & $\begin{array}{l}\text { *happy } \\
\text { *kind } \\
\text { *proud } \\
\text { *thanks }\end{array}$ & $83(27.9 \%)$ & $2(67 \%)$ & 327 (83.4\%) & $\begin{array}{l}\text { Kindness: participating students } \\
\text { treated them kindly } \\
\text { Proud of oneself for doing } \\
\text { something for others } \\
\text { Experiencing visitors' satisfactory } \\
\text { responses }\end{array}$ \\
\hline Sympathies & $\begin{array}{l}{ }^{*} \text { worthwhile } \\
\text { to do }\end{array}$ & & $1(33 \%)$ & $385(98.7 \%)$ & $\begin{array}{l}\text { Understanding of SE students' } \\
\text { difficulties } \\
\text { Wonderful experience and } \\
\text { memory }\end{array}$ \\
\hline
\end{tabular}




\section{Interest}

According to Burns et al. (2003), interest is a major reason for the citizens' involvement in science festivals. Table 5 shows the details of students' reflections. The motivations to attend SSF were teachers, friends and parents' recommendations, previous experience in attending SSF, and interest in science. Some SE students showed that they had interest in SSF since they had the experience of attending the previous year. Other students found interest by previewing some of the experiments beforehand. Most of SE students attended the festival as a school field trip. The majority of the students, however, said that they enjoyed and had fun in the festival. Among the three SE student teams who ran the SSF booth, they all submitted their reflections, one of them said,

When my teacher showed a blowhorn, I really wanted to go to SSF (Haenam)

When I heard we would attend SSF this year, I was excited and waiting for the date. Last year, I made a beautiful bracelet. I will make many other things at this SSF (Unsong)

I wanted to run a booth when I visited SSF last year. Last year a nearly blind student helped me to use a magnifier. I was very impressed at her guidance. I thought I could do something this year. I heard from Ms. Jeong [his teacher name] that my school would open a booth. Although I am not smart enough to explain science to the visitors, I asked my teacher to include me as a member. ...I helped my teacher. I carried boxes and spread water on the ground. My teacher thanked to me. I was very proud of myself (Sasang).

The above excerpts show that the previous attendance of SSF and the experience of other SE students' participation of running a booth encouraged active participation from the students. The visiting SE teachers were also encouraged to participate in the following year when they visited SSF after they saw SE teachers and students run a booth. They

Table 5 Analysis on SE and NSE students' feeling of involvement

\begin{tabular}{|c|c|c|c|c|c|}
\hline \multirow[t]{2}{*}{ Sub-themes } & \multirow[t]{2}{*}{ Key words } & \multicolumn{2}{|c|}{$\begin{array}{l}\text { No. of SE students } \\
(\%)\end{array}$} & \multirow{2}{*}{$\begin{array}{l}\text { No. of NSE } \\
(\%) \\
(N=387)\end{array}$} & \multirow[t]{2}{*}{$\begin{array}{l}\text { How did they join/ } \\
\text { participate in SSF? }\end{array}$} \\
\hline & & $N=298$ & $N=3$ & & \\
\hline $\begin{array}{l}\text { Voluntarily } \\
\text { involvement }\end{array}$ & $\begin{array}{l}\text { Last year participation/want } \\
\text { to join, be excited to join, } \\
\text { Applied, volunteer/ } \\
\text { volunteering }\end{array}$ & $\begin{array}{l}81(27.2 \%) \\
3 \text { (teachers) }\end{array}$ & & $\begin{array}{l}43(11.1 \%) \\
27(7.0 \%)\end{array}$ & $\begin{array}{l}\text { Previous experience } \\
\text { I applied for the booth } \\
\text { running club prepared } \\
\text { the experiment with } \\
\text { excitement/great } \\
\text { expectations }\end{array}$ \\
\hline Club-activities & As a club member & & & $168(43.4 \%)$ & $\begin{array}{l}\text { Club member, Club } \\
\text { teachers' announcement }\end{array}$ \\
\hline Recommendations & $\begin{array}{l}\text { Teachers, friends or } \\
\text { Parents' recommendation }\end{array}$ & $104(34.9 \%)$ & $3(100 \%)$ & $24(6.2 \%)$ & $\begin{array}{l}\text { I was happy when I } \\
\text { heard I could go to SSF. }\end{array}$ \\
\hline \multirow[t]{3}{*}{ Etc. } & & $81(27.2 \%)$ & & & $\begin{array}{l}\text { Without specific } \\
\text { clarification, but } \\
\text { expressed their interest } \\
\text { in SSF }\end{array}$ \\
\hline & & & & $14(3.6 \%)$ & $\begin{array}{l}\text { Getting the volunteering } \\
\text { hours }\end{array}$ \\
\hline & & & & $5(1.3 \%)$ & Career aspirations \\
\hline
\end{tabular}


confessed that they were scared of teaching science to their students before they visited SSF, and they never even thought of running a science booth in the first place.

For NSE students, they joined as a member of the science club at their schools. They showed interest in science and had career aspirations in science and technology fields.

The SSF is a recent annual event in Busan, so most of the booth runners and visitor students did not have enough information about SSF. Therefore, only Busan District School Board (BDSB) broadcasting team, Korea Broadcasting System and Munhwa Broadcasting System showed interests in SSF. Thus, information about it was heavily relied on the e-mail document that BDSB sent to the schools in Busan. It is known that most students received the information from their science teachers or homeroom teachers.

I would like to say my thanks to my teachers who provided the information to me and recommend me to participate in the SSF. (Sasang)

I like science and I was very happy when I heard SSF from my teacher. My class attended SSF. (Myeongjin)

A recruiting advertisement for SSF runners was announced, but I did not pay attention to it. My friend suggested participating in SSF. So, my wonderful experience started. (Bniel)

As one of Ameniti club [science club] members, I participated in SSF. I could experience the scientific principles and enhanced the understanding about $\mathrm{SE}$ students. (Bukyeong)

Since I want to be a social worker, I have an interest in SE students. When I heard about SSF, I voluntarily applied to participate in it. (Youngnam)

\section{Opinions and attitudes towards science}

The key words for opinions and attitudes toward science are "Science is $\sim$ " and the sub-themes of their opinions classified as utilitarian aspects and artistic works (Table 6).

Table 6 Analysis on SE and NSE students' Opinions and Attitudes towards Science

\begin{tabular}{|c|c|c|c|c|c|}
\hline \multirow[t]{2}{*}{ Sub-themes } & \multirow[t]{2}{*}{ Key words } & \multicolumn{2}{|c|}{ No. of SE students (\%) } & \multirow{2}{*}{$\begin{array}{l}\text { No. of } \\
\text { NSE (\%) } \\
(N=390)\end{array}$} & \multirow{2}{*}{$\begin{array}{l}\text { When did students feel } \\
\text { that science is } \sim \text { ? }\end{array}$} \\
\hline & & $(N=298)$ & $N=3$ & & \\
\hline $\begin{array}{l}\text { Science is fun } \\
\text { Science is easy }\end{array}$ & Science is & $83(27.9 \%)$ & $2(67 \%)$ & & $\begin{array}{l}\text { A curious experiment, } \\
\text { Touching chemicals } \\
\text { Activities like a game } \\
\text { Dance with robots }\end{array}$ \\
\hline Science is useful/important & & $23(7.9 \%)$ & $3(100 \%)$ & $43(11.0 \%)$ & $\begin{array}{l}\text { Useful products, } \\
\text { Understanding } \\
\text { of SE students }\end{array}$ \\
\hline Science is art/beautiful & & $21(7.0 \%)$ & & & $\begin{array}{l}\text { Cellular phone rings, } \\
\text { air clouds, luminous } \\
\text { bracelets plants }\end{array}$ \\
\hline \multirow[t]{2}{*}{ Scientists are great } & & $17(5.7 \%)$ & & $46(11.8 \%)$ & $\begin{array}{l}\text { Learn how scientific } \\
\text { principles/theories work }\end{array}$ \\
\hline & & & & & Etc. (not related to SSF) \\
\hline
\end{tabular}


Twenty-eight percent of SE students thought science is fun when they experienced dancing robots, playing soccer games using moving vacuum cleaners or computer simulations. A few students mentioned that they have not touched chemicals before they attended SSF and assumed "chemicals" were very dangerous. However, the SE students handled ammonium nitrate to make a simple air conditioner using the principle of a heat absorbing chemical reaction. These experiences enabled them to change the preconceptions that science is difficult and they learned science can be useful. When SE students saw $\mathrm{CO}_{2}$ gas spreading, or made mosquito repellent bead bracelets or bubble muffins, they expressed that science is beautiful and artistic. Some SE students used metaphors to express their opinions of science. After they did an activity that they liked, they tried to express what they felt or what their opinions were.

I made a muffin. I touched and it would immediately burst with a sound, "Pung." Science was born as a beautiful muffin on my hand. A small colored cloud of science! (Harin)

My luminous bracelet is made by science. It is beautiful. So is science. (Haesong)

Science is fun and easy. I experienced the air cannon and I learned the air is around us. Science is easy and fun if I experience it. (Woonsong)

I touched chemicals while I made a simple air conditioner. Making a chemical air conditioner was easy. Science is easy, fun and useful. (Wooseong)

In contrast to SE student, for NSE students, science is a school subject that they have to learn. Not many opinions were written about their views regarding, but they appreciated science as a good way to communicate with SE students. Some NSE students thought science is great thanks to the knowledge and procedures they learned through the experiments in SSF.

Science is important in communication with SE students: At the beginning, he did not pay attention to my explanation at all, but when I started the experiment in front of him, he calmed down and started to copy me. While doing experiments we could understand and communicate with each other.

(Yeonje)

The hands-on activity of my school team was to make a fullerene molecule model. Before SSF, I did not know what fullerene is. After I learned the molecule from my teacher, I thought scientists are great to discover new materials and new machines. (Youngnam)

\section{Learning science and learning about science}

Hodson (2008) and McComas (2004) distinguish learning science and learning about science. Learning science means that students and people learn scientific theories, principles and laws while learning about science means learning about what science is, how 
it affects society, human life, how it has been developed. This study follows their distinction.

Table 7 shows the results of the analysis of learning science and learning about science. It categorized learning scientific knowledge and learning about science such as how to collaborate, how to solve problems and how to communicate (explain) scientific knowledge to others. SE students described what they learned from the festival briefly with a couple of words. They were mostly factual knowledge and enumerated the topics which they experienced.

I made a cup of layered beverage. Before I made it, I assumed that the booth runner students put something between the layers. However, I learned that they did not put anything. I put the liquid smoothly and the layer formed. The booth runner explained that the different densities made the layers. (Koopo)

I thought all chemicals are dangerous and I should not touch them. But I touched it and I was okay. It was exciting. (Naesung)

I mixed sugar, citric acid and water and they turned into cider. It was delicious and science is fun. (Nammoon)

When ammonium nitrate meets water, it dissolves and becomes cool. Using ammonium nitrate and water I made a portable air conditioner. (Haelim)

SSF motivated the NSE students to learn science by themselves. As Table 7 shows, $37 \%$ of the participating students described that they studied more than the information that their teachers provided.

To explain the principle of how the ice cream is made, I tried to understand the principle why the salt makes the ice colder than just ice only. Thus, I searched on the internet and generated potential questions. (Namsung)

Table 7 Results of the Analysis of Learning Science and Learning about Science

\begin{tabular}{|c|c|c|c|c|c|}
\hline \multirow[t]{2}{*}{ Sub-themes } & \multirow[t]{2}{*}{ Key words } & \multicolumn{2}{|c|}{ No. of SE students (\%) } & \multirow{2}{*}{$\begin{array}{l}\text { No. of } \\
\text { NSE (\%) } \\
(N=387)\end{array}$} & \multirow[t]{2}{*}{ What did the students learn? } \\
\hline & & $(N=298)$ & $N=3$ & & \\
\hline Knowledge of science & $\begin{array}{l}\text { I learned } \\
\text { | practiced } ~ \\
\text { I understood } \sim\end{array}$ & $29(9.7 \%)$ & $1(33 \%)$ & $72(18.5 \%)$ & $\begin{array}{l}\text { Factual knowledge } \\
\text { Related to the topics } \\
\text { of the activities }\end{array}$ \\
\hline $\begin{array}{l}\text { Knowledge about science } \\
\text { (the nature of science) }\end{array}$ & & $18(6.0 \%)$ & & $67(17.2 \%)$ & $\begin{array}{l}\text { Learning how to learn/ } \\
\text { Learning how to collaborate/ } \\
\text { Learning the role of science }\end{array}$ \\
\hline $\begin{array}{l}\text { Understanding others } \\
\text { (how to communicate } \\
\text { with SE students) }\end{array}$ & $\begin{array}{l}\text { I learned } \sim \\
\text { | regretted } \sim \\
\text { | realized } \sim \\
\text { | understood } \sim\end{array}$ & $19(6.4 \%)$ & & $340(87.2 \%)$ & $\begin{array}{l}\text { NSE students' perspectives } \\
\text { (prejudice, inferior, biased } \\
\text { ideas on SE students) } \\
\text { (wearing others' shoes) } \\
\text { (Pure spirit, slow learners) } \\
\text { SE students' perspectives } \\
\text { (kind, warm, beautiful, } \\
\text { thankful) } \\
\text { Learning from other SE } \\
\text { students }\end{array}$ \\
\hline
\end{tabular}


Before participating SSF, I did not know what fullerene is. I searched fullerene on the internet and it consists of 60 carbon atoms... (Yeongnam)

Using beads, we tried to explain DNA models to the visitors. Modeling is useful to explain very small things or concepts... (Namsung)

Furthermore, while the participants were preparing in SSF, they practiced science (National Research Council, 2013). For example, the team demonstrated Pascal's law (the principle of transmission of fluid-pressure) and described how they would explain the complex scientific principles easily to visitors.

After class, my team discussed the activities to show the Pascal's law. My science teacher said, "The activities should make the visitors think twice and three times about the principle and how the principle had been applied in the outputs or games." ...In order to attract visitors' attention, we decided to employ an air cannon model. While we were preparing for SSF, we tried many boxes with different materials, different sizes of boxes and different sizes of holes. Everybody had different ideas. It was not easy to reach an agreement. Finally, we used a ramen box and the hole diameter was $15 \mathrm{~cm}$. Jeong [group member] and other 2 students would explain the principle while Young [group member] and I helped the visitors play the game to extinguish a candlelight. (Yeonje)

These excerpts demonstrated learning science and practicing science. They tried to find the optimal materials and collaborated with their peers and their science teacher.

Although not many students wrote about the difficulties or problems they experienced and how they solved the problems, the excerpts show the educational aspects of SSF. Whilst paying attention, there were a few cases to be found; a team making ear phones through teeth vibrations said,

The speaker did not work since it was too small. We tried to put it in our mouth. My friend had different ideas so he ran to a stationary store to change it. Finally, we solved the problem by connecting two speakers rather than one. (Bniel)

In order to solve the problems, they collaborated and gathered the ideas among the team members. Some mentioned that they could uncover unknown aspects about their friends while they were collaborating together and learned how to carry out teamwork, which they could not learn from classes;

I spent a lot of time preparing the experiment with senior students in my club. He explained the principle repeatedly until he thought I understood. I did not know he was such a kind and tolerant person. I reflected on that experience. It made me more collaborative and cooperative with others. (Donsung) 


\section{Integrating education}

Besides learning science, the participating students could understand the characteristics of SE students. Most NSE students appreciated the opportunity to participate in SSF and their prejudice against SE students was reduced. Before attending SSF, the participating NSE student assumed that they had to do everything for SE students, and some thought that discrimination was natural since they were inferior and had disabilities.

In my class, Jin [SE student] yells quite often. He distracts the class and gives my teacher a hard time. Before SSF, I mostly tried to avoid him. The lecture made me think SE students are normal people although they need more help than others. Now I am trying to help him and want to listen to him. (Centum).

While I was preparing SSF with Sena [SE student], I learned that she is not a fool but a slow learner. I told her to write her name on the name tag, she was very cautious not to make mistakes and asked me twice. I told her not to worry about making mistakes. Her writing was more legible than mine although it took much longer than how I would normally take. (Nakdong).

Besides the excerpts above, almost all NSE students mentioned that they could be a friend with SE students and would help them if they are in need.

SSF was a good place where both participating student groups and visitors could communicate and practice science. For SE students when they were involved in hands-on activities and the positive outcomes of the experiment contented them, they regarded science as fun and useful for their lives. The experience of visiting SSF encouraged the visitors to voluntarily take part of science experiments done by booth runners. This means that a science festival could be a good way to communicate science for SE students and teachers. A science festival could be a motivation for NSE students to learn science and learn about science. The processes of deciding topics, materials, dividing roles, reaching an agreement and collaborating with others were excellent chances for students to develop their problem-solving skills. They also enhanced their learning in science while they were preparing clear and simple explanations of scientific principles. Furthermore, both NSE and SE students learned the ways to communicate with each other through science so that the NSE students' bias about SE students were reduced or changed while they were preparing for and participating in the science festival.

\section{Conclusion and suggestions}

As the conceptual framework illustrates, these results show the visitor SE students' positive impressions and how much they enjoyed science in SSF as well as the insightful understanding of NSE students of SE students. The results reveal how science communication has occurred in a science festival emphasizing the two aspects: 1) the feelings of the students (reasons of participating and visiting SSF) and 2) learning science and learning about science. The followings are the summary of the findings; SSF is

- a very fun and enjoyable event for both SE and NSE students whether they were running or visiting science experiment booths, 
- a place for students to do science,

- an opportunity for both SE and NSE students to experience a diverse range of science activities,

- a place that enables students to be more aware of the procedures of knowledge attainment and applications of scientific knowledge are embodied in everyday life,

- an event that enhances the understanding of NSE students about SE students, and

- where active participation of students encourages them to be proud of themselves and become confident in performing a scientific demonstration in front of others.

These positive findings could support the idea that science festivals like SSF is an effective way to achieve the goal of science education, 'science for all.' To fulfill this goal, these festivals should be widely spread around the nation for the fairness to SE students outside of Busan. Also, NSE students need opportunities to practice the scientific knowledge which they have learned from class. Doing science makes science relevant and authentic for students. The experiences inspire future citizens to participate actively in the decision-making process that affects the society and science itself.

The reflective writings and drawings of the students and participating teachers' opinions led the authors to do some suggestions for future science festivals for SE students. The disabilities and/or conditions of SE students are diverse. Some have challenges in learning, some have physical challenges in walking and detailed muscle movement, so the organizers of a festival should include the specialists' consultants from the special education field.

Firstly, SE students have a range of learning disabilities that should be taken into consideration. In SSF, a few SE students mentioned that some activities were scary while others thought that the same activities were exciting. This implies that some experiments are not suitable for certain students. The organizers of a science festival should give detailed information about the experiments to SE teachers prior to attendance. This way, the teachers can check which activities are proper and within the students' comfort limits. The organizers should also ask the SE teachers to explain to SE students about the festival atmosphere before they attend. The festival can be loud or crowded with new people, therefore the students should be prepared for certain situations in order not to be frightened or overwhelmed. The booth runners including their supervising teachers need to explain to the visitors the activities before their presentation to prevent panic or emergency situations.

Secondly, the accessibility of the venue of a science festival such as a resting area is a necessity. With many people and new environment, SE students are more likely to get tired in the unfamiliar situation. The authors recommend a resting area every 10 booth to provide enough seats for those who need them.

Thirdly, in SSF, many NSE students appreciated the preliminary lecture to help understand SE students' behaviors that may be unfamiliar to them. They found it was very effective to select topics, prepare materials and brainstorm strategies in how to explain the science experiment to SE students. This is important because without proper preparation, the booth runners might fail to communicate science with SE students smoothly and naturally if they do not have enough understanding about the characteristics of SE students. As an example, excessive gestures or kindness might be frustrating and uncomfortable for SE students. Therefore, the organizers should offer the booth 
runners of NSE students and supervising teachers with an opportunity to learn about SE students' behaviors and needs.

Furthermore, in order for these results not to be from a one-time event, continuous studies are needed to examine how the experience affects students' attitudes towards science, and how they might be able to connect the experience with science learning in school. Potocnik (2005) said that science festivals are an effective way to communicate science to the public. However, without research-based evidence, his argument cannot be proven valid. So far, this study has provided evidence to support his argument. In SSF, the participants and visitors learned science and interacted with each other through science as well as enhanced mutual understanding of each other. NSE students widened and deepened their knowledge related to the topics presented at the festival. They also practiced science, while they were preparing for the festival by selecting topics, thinking of potential questions and problems, searching for solutions, and collaborating with their group members. These are what McCallie et al. (2009) emphasized mutual learning in science communication.

\section{Endnotes}

${ }^{1}$ 'Seullim,' a Korean language, means a small vibration or ringing sound towards the world.

\section{Appendix}

Table 8 Content of the Science Experiments in 2014

\begin{tabular}{ll}
\hline No. & Content \\
\hline 1 & Fire! Air cannon \\
3 & Air gun \\
4 & Burning candle light \\
5 & Straw fountain \\
6 & Let play with oxygen \\
7 & Growing concentration \\
8 & Making a Bubujella horn \\
9 & experiencing a boomerang plane (love will come back) \\
10 & A marble for all \\
11 & Making a rubber powered cart \\
12 & Spacecraft made of a CD \\
13 & A mini fan using charcoal batter \\
14 & A speaker hearing through teeth \\
15 & Wind blows \\
16 & Play Jwibul \\
17 & Wow, look big \\
18 & Appear or disappear! Polarization magic cards \\
19 & Glow in the world of light \\
20 & Hologram on my hand \\
21 & Making a scarecrow hanging on the finger tip \\
& Elsa's ice kingdom \\
\hline & Butterflies who you are! \\
\hline & \\
\hline &
\end{tabular}


Table 8 Content of the Science Experiments in 2014 (Continued)

\begin{tabular}{|c|c|}
\hline No. & Content \\
\hline 23 & A neofinetia falcata embraces Sora \& Animal Therapy \\
\hline 24 & Making Pepero ice cream \\
\hline 25 & Create a Baskin Robbins ice cream \\
\hline 26 & Seven princesses' bubble kingdom \\
\hline 27 & Bloated cake and shake! \\
\hline 28 & Science through chocolate, Beniel chocolate factory \\
\hline 29 & Experiencing a thermoplastic ear caps \\
\hline 30 & Sparkling bracelets \\
\hline 31 & Faddist flowers and a finger copy \\
\hline 32 & Making a shining lightsaber \\
\hline 33 & Flame magic \\
\hline 34 & Create your own toys with magnets: Create your own picture mirror \\
\hline 35 & Create your own unbreakable mirror \\
\hline 36 & Experience a three-dimensional celestial constellation \\
\hline 37 & Making a hair essence \\
\hline 38 & Making a natural herbal ointment- Zaoongo \\
\hline 39 & Kaleidoscope in vitro into the kingdom of fantasy! \\
\hline 40 & Experience the magic world of science \\
\hline 41 & Making a simple air conditioner \\
\hline 42 & A crystal ball, Blooming roses in the night \\
\hline 43 & Making a mouthwash EM natural toothpaste \\
\hline 44 & Move the woodpecker! \\
\hline 45 & An alcohol pistol hides scientific principles \\
\hline 46 & Relaxation and mosquito eradication at the same time with aroma \\
\hline 47 & See the sun \\
\hline 48 & Experience of the osmosis principle \\
\hline 49 & Anodizing \\
\hline 50 & Making a Lava lamp using the density difference \\
\hline 51 & Experience the magic of light \\
\hline 52 & Making your own mirror with etched stainless steel \\
\hline 53 & A frozen winter kingdom \\
\hline 54 & Goal in a fullerene ball \\
\hline 55 & Experience the world of constellation \\
\hline 56 & Experience how to make an ice cream \\
\hline 57 & Experiencing $\mathrm{CIS}$ \\
\hline 58 & Experience aroma \\
\hline 59 & Making a sunlight bracelet \\
\hline 60 & Experience weather reports \\
\hline 61 & Making a wind gauge \\
\hline 62 & Experience the robot world - dancing robots \\
\hline 63 & Experience LG (electronic company) \\
\hline 64 & Experience face-paining \\
\hline 65 & Let's play with nature \\
\hline 66 & Experience the robot world - soccer game \\
\hline
\end{tabular}


Table 8 Content of the Science Experiments in 2014 (Continued)

\begin{tabular}{ll}
\hline No. & Content \\
\hline 67 & I am a robot controller \\
68 & Marbling \\
69 & Making a wooden bracelet \\
70 & Experience the spacecraft \\
71 & Experience spectroscopy \\
72 & Experience the handling simulator of aircrafts \\
\hline
\end{tabular}

\section{Abbreviations}

BDSB: Busan District School Board; BISE: Busan Institute of Science Education; NSE: Non special education; SE: Special education; SSF: Seullim science festival

\section{Acknowledgements}

Not applicable

\section{Authors' contributions}

HP; research plan \& participants interview. YK; paper construction and elaboration. SJ: field observation and data analysis. All authors read and approved the final manuscript.

\section{Funding}

Not applicable

Availability of data and materials

Not applicable

\section{Competing interests}

The authors declare that they have no competing.

\section{Publisher's Note}

Springer Nature remains neutral with regard to jurisdictional claims in published maps and institutional affiliations.

\section{Author details}

${ }^{1}$ Busan Institute of Science Education, Busan, Republic of Korea. ${ }^{2}$ Pusan National University, Busandaehakro, 63 bun-gil

2, Busan 46241, Republic of Korea. ${ }^{3}$ Myeongho High School, Busan, Republic of Korea.

Received: 5 October 2018 Accepted: 27 December 2018

Published online: 24 January 2019

\section{References}

Bultitude, K. (2011). The why and how of science communication. In: Rosulek,P., ed. Science Communication. Pilsen:European Commission.

Burns, T. W., O'Connor, D. J., \& Stocklmayer, S. M. (2003). Science communication: A contemporary definition, public understanding of science 12; 183. Sage Publications.

Gibbs, G. (2010). Core Elements part 1 Grounded Theory. United Kingdom: University of Huddersfield. Available from http:// www.youtube.com/watch?v=4SZDTp3_New

Glaser, B. G., \& Strauss, A. L. (1967). The discovery of grounded theory. Strategies for qualitative research. Chicago: Aldine.

Gross, G. A. (1994). The roles of rhetoric in the public understanding of science. Public Understanding Science, 3(23), 3-23.

Hodson, D. (2008). Towards scientific literacy: A teachers' guide to the history, philosophy and sociology of science. Rotterdam: The Netherlands, Sense Publishers.

Holliman, R., \& Jensen, E. (2009). (In)authentic science and (im)partial publics: (Re)counstructing the science outreach and public engagement agenda. In R. Holliman, E. Whitelegg, E., Scanlon, S. Smidt \& J. Thomans (Eds.), Investigating Science Communication in the Information Age: Implications for Public Engagement and Popular Media (pp. 35-52). Oxford, England: Oxford University Press.

Im, S., Cha, J., \& Kim, H. (2018). A case study on science education for students with special educational needs and the change of pre-service science teachers' attitude towards disability and inclusive. Journal of Korean Association for Science Education, 38(1), 87-96.

Irwin, A. (2006). The politics of talk: Coming to terms with the 'new' scientific governance. Social Studies of Science, 36(2), 299-320. Jensen, E. (2011). Evaluate impact of communication. Nature, 469, 162.

Jensen, E. (2014a). Why people attend science festivals: Interests, motivations and self-reported benefits of public engagement with research. Public Understanding of Science, 23(5), 557-573.

Jensen, E. (2014b). The problem with science communication evaluation. Journal of Science Communication, 13(1), 1-3. Jensen, E., \& Buckley, N. (2011). The Role University student volunteers in festival-based public engagement. Bristol: National Coordinating Centre for Public Engagement. 
Jensen, E., \& Buckley, N. (2012). Why people attend science festivals: Interests, motivations and self-reported benefits of public engagement with research. Public Understanding of Science, 23(5), 557-573.

Kang, D., \& Martin, S. (2017). Challenging pre-service science teachers' beliefs about inclusion science classroom through experimental learning. The Journal of Special Education: Theory and Practice, 18(4), 327-356.

McCallie, E., Bell, L., Lohwater, T., Falk, J. H., Lehr, J. L., Lewenstein, B. V., Needham, C., \& Wiehe, B. (2009). Many experts, many audiences: Public engagement with science and information science education. Washington: Centre for Advancement of Informal Science Education.

McComas, W. F. (2004). Keys to teaching the nature of science. The Science Teacher, 71(9), 24-27.

Ministry of Education of Korea. (2015). Science and curriculum. Ministry of Education notice 2015-74. In Seoul; ministry of education.

Myers, T., Kotcher, J., Cook, J., Beall, L., Maibach, E. (April, 2018). March for Science 2017: A Survey of Participants and Followers. George Mason University. Fairfax, VA: George Mason University Center for Climate Change Communication.

National Research Council. (2013). Next generation science standards: for states, by states. Washington DC: The National Academies Press. https://doi.org/10.17226/18290.

Osborne, J. (2000). Science for citizenship. In Osborne, J. and monk, M. Good practice in science teaching: What research has to say. Buckingham: Open University Press.

Park, H., Khan, S., \& Petrina, S. (2009). ICT in science education: A quasi-experimental study of achievement, attitudes toward science, and career aspirations of Korean middle school students. International Journal of Science Education, 31(8), 993-1012.

Potocnik, J. (2005). Science communication events in Europe: EUSCEA white book. Available from http:/www.eusea.info/wpcontent/uploads/2016/10/EUSEA_White_Book.pdf. Accessed 25 Feb 2015.

Submit your manuscript to a SpringerOpen ${ }^{\circ}$ journal and benefit from:

- Convenient online submission

- Rigorous peer review

- Open access: articles freely available online

High visibility within the field

- Retaining the copyright to your article

Submit your next manuscript at $\boldsymbol{\nabla}$ springeropen.com 